\title{
Pengembangan game edukasi labirin matematika untuk meningkatkan kemampuan pemecahan masalah siswa kelas VI sekolah dasar
}

\author{
Pelagia Angwarmasse ${ }^{\left.{ }^{*}\right)}$, Wahyudi Wahyudi ${ }^{1}$ \\ ${ }^{1}$ Universitas Kristen Satya Wacana
}

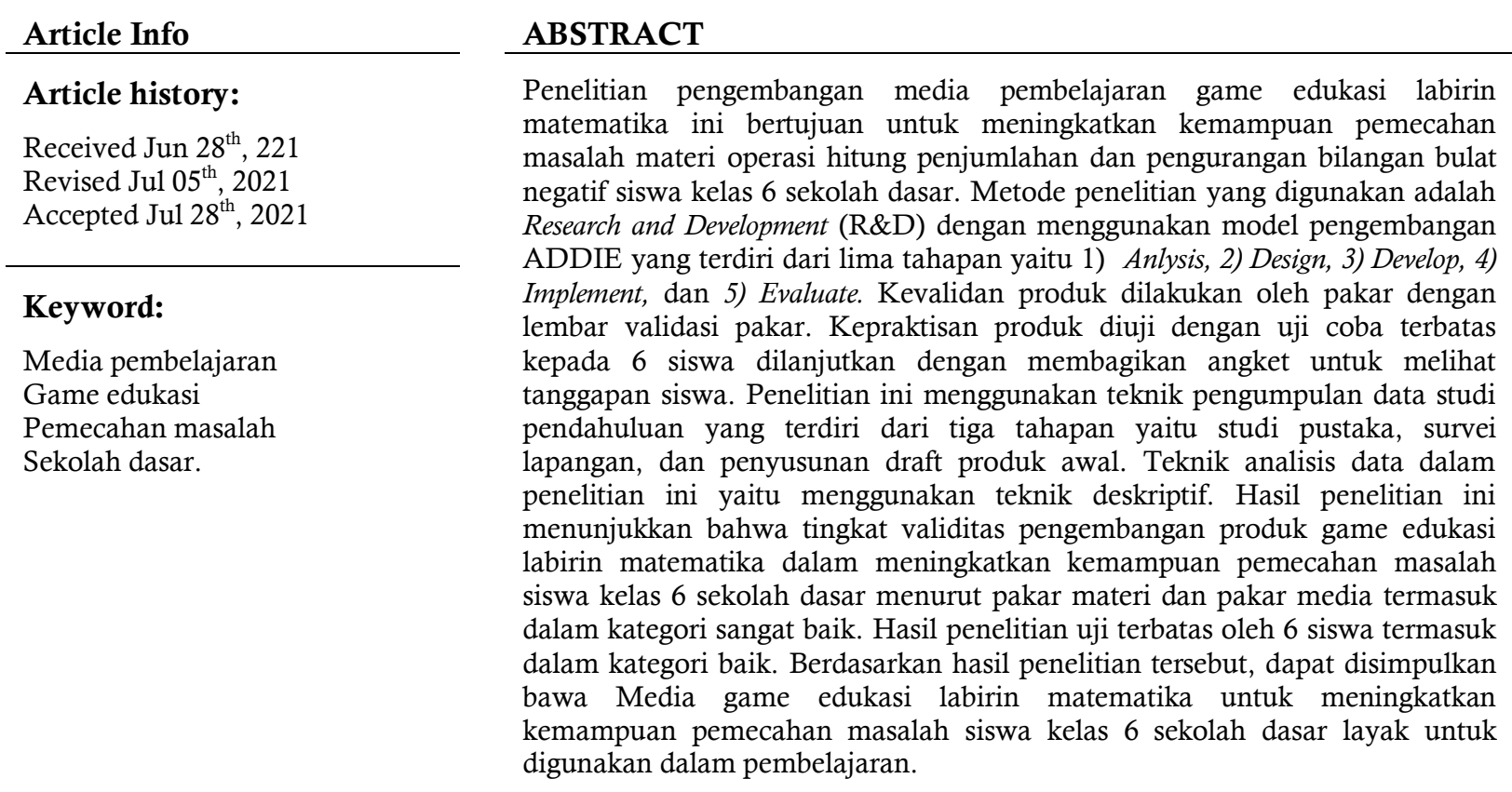

(C) 2021 The Authors. Published by IICET.

This is an open access article under the CC BY-NC-SA license

\section{Corresponding Author:}

Pelagia Angwarmasse

Universitas Kristen Satya Wacana

Email: 292017027@student.uksw.edu

\section{Pendahuluan}

Pendidikan adalah usaha manusia untuk menumbuhkan dan mengembangkan potensi baik secara rohani maupun jasmani yang sesuai dengan nilai-nilai didalam masyarakat dan kebudayaan (Fuad Ihsan, 2005 : 1). Hal ini sejalan dengan UU No. 20 tahun 2003 tentang SISDIKNAS bahwa pendidikan adalah usaha sadar yang direncanakan untuk mewujudkan suasana proses belajar mengajar agar peserta didik mampu secara aktif meningkatkan potensi yang dimiliki seperti, spiritualitas, kepribadian, pengendalian diri, akhlak mulia, kecerdasan, dan keterampilan yang dibutuhkan untuk diri sendiri dan juga masyarakat. Hal senada juga disampaikan oleh Oemar Hamalik (2001 : 79), bahwa pendidikan adalah proses dan upaya untuk 
mempengaruhi peserta didik belajar menyesuaikan diri dengan lingkungan dengan tujuan menimbulkan perubahan bagi peserta didik untuk berfungsi dalam kehidupan bermasyarakat.

Pada waktu sekarang ini, di tahun 2020 dunia diguncang musibah yang belum pernah terjadi sebelumnya yaitu adanya pandemi Covid-19. Hal ini menyebabkan terganggunya aktivitas penduduk di seluruh dunia salah satunya dalam bidang pendidikan. Banyak negara termasuk Indonesia yang harus menutup sekolah, perguruan tinggi maupun universitas untuk mengurangi adanya kontak secara langsung dengan orang sekitar dan untuk menyelamatkan hidup. Dampak dari adanya pandemi Covid-19 dalam bidang pendidikan adalah peserta didik harus belajar dari rumah dan proses belajar mengajar dilakukan secara daring. Dalam Permendikbud No. 109/2013 pendidikan jarak jauh adalah suatu proses belajar mengajar secara jarak jauh dengan menggunakan berbagai media komunikasi.

Pembelajaran matematika sampai sekarang ini masih menjadi mata pelajaran yang dianggap sulit, khususnya untuk siswa sekolah dasar. Matematika merupakan pengetahuan dasar yang harus dimiliki oleh siswa untuk mencapai suatu keberhasilan pembelajaran. Salah satu faktor dalam diri siswa yang dapat mempengaruhi hasil belajarnya adalah minat belajar. Hal yang dapat dilakukan yaitu dengan memanfaatkan kemajuan teknologi informasi dan komunikasi dalam bidang pendidikan (Sarama \& Clements, 2009).

Perkembangan teknologi dan informasi membawa perubahan besar dalam bidang pendidikan seiring dengan kemajuan zaman. Dampak positif dengan adanya perkembangan teknologi dalam dunia pendidikan adalah guru maupun peserta didik dapat dengan mudah menemukan dan mencari informasi. Sekarang ini, dalam bidang pendidikan banyak yang memanfaatkan teknologi sebagai sarana informasi dan pengetahuan melalui internet (Ratminingsih, 2020 : 1). Guru menyampaikan materi pembelajaran kepada siswa melalui media yang dibuat dengan memanfaatkan teknologi. Salah satu teknologi yang dapat dimanfaatkan adalah teknologi berupa game edukasi.

Game dapat diartikan sebagai suatu kegiatan atau aktivitas yang dilakukan oleh satu atau lebih pemain dengan adanya aturan tertentu, dalam game biasanya ada yang menang dan ada yang kalah dengan tujuan untuk bersenang-senang atau refreshing (Febriyanto Pratama Putra, 2012). Selain itu, game juga berfungsi sebagai sarana latihan, pendidikan, dan simulasi. Menurut (Marc Prensky, 2012) game edukasi didesain sebagai sarana untuk belajar, agar lebih menyenangkan. Berdasarkan pendapat tersebut dapat disimpulakan bahwa, game edukasi merupakan gabungan dari konten pendidikan dan game komputer.

Game yang dipilih peneliti adalah game edukasi. Jenis permainan (genre game) yang dipilih peneliti adalah genre maze yaitu permainan lorong-lorong yang saling berhubung. Peneliti memilih game edukasi karena game ini digunakan sebagai media pembelajaran matematika yang akan diterapkan pada siswa sekolah dasar agar dapat meningkatkan kemampuan pemecahan masalah siswa. Sedangkan, peneliti memilih genre maze karena siswa harus mencari jalan keluar dengan bantuan petunjuk soal yang ada disetiap belokan dengan waktu tercepat yang diperoleh. Game Labirin (maze) dapat membantu anak bermain tantangan dengan mengenalkan petualangan demi melatih keterampilan anak dalam menghadapi berbagai rintangan.

Pemanfaatan game Labirin Matematika ditujukan untuk siswa kelas VI SD. Siswa sekolah dasar sangat memiliki ketertarikan yang tinggi terhadap game. Game mampu menarik minat siswa untuk memainkannya, karena di dalam game terdapat rasa keingintahuan yang tinggi. Perasaan keingintahuan yang tinggi terhadap game akan membawa siswa menjadi senang dalam memainkan game tersebut hingga selesai.

Media pembelajaran yang melibatkan siswa aktif di kelas khususnya media berbasis game edukasi yang ada saat ini, dirasa masih kurang maksimal dalam penggunaannya khususnya pada anak sekolah dasar dan belum banyak dimanfaatkan oleh guru. Media yang ada seperti Media Pembelajaran Berbasis Game Android untuk Meningkatkan Minat Belajar Materi Operasi Hitung Bilangan Bulat (Rahman: 2020), Media Pembelajaran Berbasis Game Edukasi Labirin Matematika sebagai Media Latihan Soal Materi Bilangan (Erva: 2019), dan Media Labyrinth Adventure Berbasis Andorid Sesuai Tahapan Pemecahan Masalah Polya di Sekolah Dasar (Novita Ely Wardhani : 2020), semua media yang sudah dikembangkan sangat inovatif dan kreatif, tetapi media tersebut masih banyak digunakan untuk siswa SMP dan untuk anak usia SD masih sangatlah sedikit, sehingga perlu dikembangkan lagi. Selain itu, produk yang dikembangkan, untuk pelajaran matematika khususnya operasi hitung bilangan bulat negatif masih sangat sedikit. Oleh karena itu, peneliti akan mengembangkan media pembelajaran berbasis game edukasi untuk meningkatkan kemampuan pemecahan masalah pada materi operasi hitung bilangan bulat negatif.

Berdasarkan hasil wawancara yang telah dilakukan dengan guru kelas VI SD Negeri Dukuh 01 Salatiga, maka didapatkan informasi bahwa selama pembelajaran daring berlangsung peserta didik mengalami beberapa kendala salah satunya masalah sinyal. Selain itu, pembelajaran yang dilakukan melalui google meet peserta didik cenderung mematikan kamera dan jika diberikan pertanyaan oleh guru peserta didik hanya diam 
saja dan ada juga peserta didik yang meninggalkan google meet saat pembelajaran berlangsung tanpa se izin dari bapak/ibu guru. Selama pembelajaran daring peserta didik mengalami kesulitan saat memahami materi, khususnya mata pelajaran matematika materi operasi hitung penjumlahan dan pengurangan bilangan bulat negatif. Peserta didik belum memahami konsep yang ada, sehingga ketika diberikan sebuah soal peserta didik asal mengerjakan dan terburu-buru tanpa mengoreksi jawabannya kembali. Selain itu, di SD Negeri Dukuh 01 Salatiga sebelumnya sudah ada produk berupa board game dan untuk game edukasi sendiri peserta didik baru diperkenalkan dari segi PC nya saja.

Berdasarkan pernyataan-pernyataan di atas, peneliti akan mengembangkan suatu produk penelitian yaitu media pembelajaran berbasis game edukasi untuk meningkatkan kemampuan pemecahan masalah matematika kelas VI SD. Dalam penggunaannya, siswa akan memecahkan permasalahan tentang operasi hitung penjumlahan dan pengurangan bilangan bulat negatif. Pengembangan game edukasi berbasis android ini memberikan beberapa kelebihan yaitu game edukasi berbasis android ini dikemas dalam bentuk permainan yang dipasang di android agar lebih mudah dan praktis dalam menggunakannya karena dapat diakses dimana saja dan kapan saja. Dalam permainan game, siswa diminta untuk memecahkan masalah dengan menjawab soal-soal yang mana melalui kegiatan ini diharapkan dapat membantu dalam menghadapi berbagai masalah dalam kehidupan nyata. Selain itu, siswa akan aktif serta tertarik untuk memainkannya, tanpa disadari mereka sudah belajar dengan bermain. Dengan demikian siswa yang merasa kesulitan dan siswa yang tidak suka matematika akan menjadi lebih bersemangat untuk belajar matematika. Berdasarkan latar belakang tersebut, maka peneliti tertarik untuk melakukan penelitian pengembangan dengan judul "Pengembangan Game Edukasi Labirin Matematika untuk Meningkatkan Kemampuan Pemecahan Masalah Kelas VI SD".

\section{Metode}

Penelitian yang digunakan adalah jenis penelitian dan pengembangan atau Research \& Development (R\&D). Menurut Borg \& Gall (2007: 589), penelitian dan pengembangan merupakan penggunaan suatu temuan penelitian untuk merancang produk dan prosedur baru, melalui metode penelitian diantaranya pengujian lapangan, evaluasi, dan penyempurnaan hingga memenuhi kriteria keefektifan, kualitas, atau standar yang ditentukan. Sedangkan menurut Sukmadinata (2016:164), penelitian pengembangan merupakan suatu proses untuk mengembangkan produk baru atau produk yang sudah ada sehingga dapat dipertanggungjawabkan. Penelitian pengembangan ini menghasilkan produk berupa game edukasi labirin matematika yang bertujuan untuk meningkatkan kemampuan pemecahan masalah siswa kelas VI sekolah dasar

\section{Hasil dan Pembahasan}

Pada tahap pengembangan, media yang sudah dibuat sebelumnya akan dilakukan uji validitas terlebih dahulu sebelum diterapkan di sekolah dasar. Terdapat dua proses uji validitas yang dilakukan yaitu uji validitas materi dan uji validitas media. Validator akan memberikan penilaian berdasarkan aspek kelayakan media yang sudah dikembangkan oleh peneliti dan memberika saran serta komentar yang nantinya akan menjadi bahan revisi dan penyempurnaan media.

\section{Hasil validasi pakar media}

Validasi pakar media pada game edukasi labirin matematika dilakukan oleh dosen PGSD, FKIP, Universitas Kristen Satya Wacana, Salatiga. Tujuan dari validasi media ini yaitu untuk mengetahui kelayakan dari produk game labirin matematika yang dikembangkan dari aspek tampilan, interaksi, kontrol, dan bentuk. Validator akan memberikan saran dan komentar jika media tersebut kurang sesuai. Saran dan komentar dari validator akan digunakan sebagai dasar peneliti untuk melakukan revisi hingga media tersebut layak untuk digunakan. Validasi media dilakukan dengan memberikan rubrik instrumen uji validasi media yang terdapat 14 indikator dengan skor maksimal 4 dan skor minimal 1 dari masing-masing indikator. Data hasil validasi ahli media disajikan dalam tabel 1.

Tabel 1. Data Hasil Validasi Ahli Media

\begin{tabular}{cllc}
\hline Aspek & \multicolumn{1}{c}{ Indikator } & Skor \\
\hline Tampilan & 1. & Media relevan dengan materi pembelajaran & 4 \\
\cline { 2 - 4 } & 2. & Background media menarik & 3 \\
\hline 3. & $\begin{array}{l}\text { Pemilihan warna untuk backgorund dan elemen } \\
\text { gambar sudah baik dan menarik }\end{array}$ & 3 \\
& 4. & Jenis huruf pada teks mudah dibaca \\
& 5. & Ukuran huruf yang digunakan sudah sesuai dengan \\
& konten media & 3 \\
\hline
\end{tabular}




\begin{tabular}{|c|c|c|}
\hline Aspek & Indikator & Skor \\
\hline \multirow[t]{3}{*}{ Interaksi } & $\begin{array}{l}\text { 6. Adanya umpan balik terhadap respon siswa ketika } \\
\text { menekan atau mengklik tombol }\end{array}$ & 3 \\
\hline & 7. Topik pembahasan lengkap dan urut & 4 \\
\hline & $\begin{array}{l}\text { 8. Adanya pemberitahuan skor atau grade pada kuis } \\
\text { dalam media }\end{array}$ & 4 \\
\hline \multirow[t]{3}{*}{ Kontrol } & 9. Tombol untuk mengakses materi mudah digunakan & 3 \\
\hline & $\begin{array}{l}\text { 10. Tombol untuk mengakses kuis dan games mudah } \\
\text { digunakan }\end{array}$ & 3 \\
\hline & 11. Panel untuk interaktivitas mudah digunakan & 2 \\
\hline \multirow[t]{5}{*}{ Bentuk } & 12. Animasi pada media sesuai dengan materi & 4 \\
\hline & 13. Animasi pada media menarik & 3 \\
\hline & 14. Animasi mudah dipahami & 3 \\
\hline & Jumlah & 45 \\
\hline & Persentase & $80,3 \%$ \\
\hline
\end{tabular}

Berdasarkan hasil validasi oleh pakar media, media game edukasi labirin matematika yang peneliti kembangkan mendapatkan jumlah skor 45 dengan persentase 80,3\%, termasuk dalam kategori sangat baik dan layak untuk digunakan.

Hasil validasi pakar materi

Validasi pakar materi pada game edukasi labirin matematika dilakukan oleh dosen PGSD, FKIP, Universitas Kristen Satya Wacana, Salatiga. Tujuan dilakukan validasi materi yaitu untuk menilai relevansi, keakuratan, dan sistematika sajian pada game edukasi labirin matematika. Validator akan memberikan saran dan komentar jika materi yang ada pada media ada yang kurang sesuai. Saran dan komentar dari validator akan dijadikan sebagai dasar peneliti untuk melakukan revisi hingga materi layak untuk diajarkan. Validasi materi dilakukan dengan memberikan rubrik instrumen uji validasi materi yang terdapat 12 indikator dengan skor maksimal 4 dan skor minimal 1 dari masing-masing indikator. Data hasil validasi ahi materi disajikan dalam tabel 2 berikut :

Tabel 2. Data Hasil Validasi Ahli Materi

\begin{tabular}{|c|c|c|}
\hline Aspek & Indikator & Skor \\
\hline \multirow[t]{7}{*}{ Relevansi } & $\begin{array}{l}\text { 1. Materi relevan dengan kompetensi yang harus dikuasai peserta } \\
\text { didik. }\end{array}$ & 3 \\
\hline & $\begin{array}{l}\text { 2. Soal / kuis relevan dengan kompetensi yang dikuasai peserta } \\
\text { didik. }\end{array}$ & 3 \\
\hline & $\begin{array}{l}\text { 3. Penjelasan materi relevan dengan kompetensi yang harus } \\
\text { dikuasai peserta didik. }\end{array}$ & 4 \\
\hline & $\begin{array}{l}\text { 4. Kedalaman uraian materi sesuai dengan tingkat perkembangan } \\
\text { peserta didik. }\end{array}$ & 3 \\
\hline & $\begin{array}{l}\text { 5. Kelengkapan materi sesuai dengan tingkat perkembangan } \\
\text { peserta didik. }\end{array}$ & 3 \\
\hline & 6. Jumlah ilustrasi cukup. & 3 \\
\hline & 7. Jumlah latihan soal cukup. & 4 \\
\hline \multirow[t]{2}{*}{ Keakuratan } & 8. Materi yang disajikan sesuai dengan kebenaran keilmuan. & 4 \\
\hline & $\begin{array}{l}\text { 9. Materi yang disajikan ssesuai dengan tingkat perkembangan } \\
\text { peserta didik }\end{array}$ & 4 \\
\hline Aspek & Indikator & Skor \\
\hline \multirow[t]{5}{*}{$\begin{array}{l}\text { Sistematika } \\
\text { Sajian }\end{array}$} & 10. Uraian materi mengikuti alur pikir dari sederhana ke kompleks. & 3 \\
\hline & 11. Uraian materi sesuai dengan pembelajaran matematika. & 3 \\
\hline & 12. Kejelasan bahasa yang digunakan & 3 \\
\hline & Jumlah & 40 \\
\hline & Persentase & $83,3 \%$ \\
\hline
\end{tabular}

Berdasarkan hasil validasi oleh pakar materi, media game edukasi labirin matematika yang peneliti kembangkan mendapatkan jumlah skor 40 dengan persentase 83,3 termasuk dalam kategori sangat baik dan layak untuk digunakan. 
Tahap selanjutnya adalah implementasi. Tahap implementasi dilakukan jika produk media sudah direvisi berdasarkan saran dari validator. Subjek pada penelitian ini adalah siswa kelas 6 SD Negeri Dukuh 01 Salatiga. Produk diujicobakan kepada 4 siswa. Setelah selesai menggunakan media pembelajarann, siswa diminta untuk mengisi angket. Hasil respon siswa berupa angket akan dijadikan sebagai dasar untuk mengetahui kepraktisan dari media game edukasi labirin matematika. Hasil respon siswa dapat dilihat pada tabel 4.3 berikut ini :

Tabe1 3. Hasil Respon Siswa

\begin{tabular}{clc}
\hline No & \multicolumn{1}{c}{ Pertanyaan } & Skor \\
\hline 1 & $\begin{array}{l}\text { Saya merasa senang ketika belajar matematika menggunakan media pembelajaran } \\
\text { berupa game edukasi }\end{array}$ & 22 \\
\hline 2 & Saya tertarik untuk belajar matematika dengan adanya media pembelajaran & 22 \\
\hline 3 & Saya mengikuti pembelajaran matematika hingga selesai & 23 \\
\hline 4 & Saya memperhatikan dengan baik materi yang disampaikan & 20 \\
\hline 5 & Saya selalu mengerjakan soal yang ada di media pembelajaran game edukasi & 20 \\
\hline 6 & Saya mengerjakan soal dengan bertanya kepada teman yang lain & 7 \\
\hline 7 & Saya putus asa ketika mengerjakan soal & 10 \\
\hline 8 & Saya semangat untuk belajar karena medianya menarik dan menyenangkan & 21 \\
\hline 9 & Saya dapat menggunakan media pembelajaran dengan lancar & 22 \\
\hline 10 & Dengan menggunakan media game edukasi dapat menambah pengetahuan saya \\
\hline 11 & $\begin{array}{l}\text { Dengan menggunakan media game edukasi dapat meningkatkan kemampuan } \\
\text { pemecahan masalah saya }\end{array}$ & 22 \\
\hline 12 & \begin{tabular}{l} 
Ketika saya mengalami kesulitan, saya bertanya kepada guru melalui whatsapp \\
\hline
\end{tabular} & 21 \\
\hline & $\quad$ Jumlah & 20 \\
\hline & $\quad$ Presentase & $79,9 \%$ \\
\hline
\end{tabular}

Berdasarkan hasil respon peserta didik setelah menggunakan game edukasi labirin matematika mencapai angka presentase sebesar 79,9\% dengan kategori baik, sehingga dapat disimpulkan bahwa peserta didik dalam proses pembelajaran dapat memahami materi dan memperoleh kepraktisan ketika menggunakan media game edukasi labirin matematika.

Pada penelitian ini menghasilkan produk game edukasi labirin matematika pada materi operasi hitung penjumlahan dan pengurangan bilangan bulat negatif siswa kelas 6 SD. Penelitian dan pengembangan ini menggunakan moedel pengembangan ADDIE (Branch, 2009:1) yang terdiri dari lima tahapan yaitu Analysis (Analisis), Design (Perancangan), Development (Pengembangan), Implementation (Implementasi), dan Evaluate (Evaluasi).

Langkah awal yang dilakukan oleh peneliti adalah mengambil data dengan melakukan wawancara dengan guru kelas 6 SD Negeri Dukuh 01 Salatiga. Dari hasil wawancara diperoleh bahwa guru menggunakan media berupa video pembelajaran dan power point dan sebelumnya guru belum menggunakan media berupa game edukasi. Oleh karena itu, peneliti tertarik untuk mengembangkan media game edukasi labirin matematika untuk diterapkan di sekolah dasar. Sesuai dengan pendapat Handriyantini (2009) yaitu dengan menggunakan game edukasi dapat meningkatkan konsentrasi dan merangsang daya pikir media yang unik dan menarik, serta menunjang proses belajar mengajar dengan kegiatan yang lebih kreatif dan menyenangkan.

Pada saat merancang media pembelajaran, peneliti melakukan beberapa hal yaitu yang pertama menentukan judul dengan tema game edukasi labirin matematika, menyiapkan sumber dari berbagai buku dan internet, serta merancang isi media game edukasi. Ketika menentukan sebuah judul harus disesuaikan dengan kompetensi dasar, indikator, dan materi pembelajaran matematika yaitu operasi hitung penjumlahan dan pengurangan bilangan bulat negatif. Media dirancang berdasarkan KD 3.2 Menjelaskan dan melakukan operasi penjumlahan, pengurangan, perkalian, dan pembagian yang melibatkan bilangan bulat negatif.

Dalam pengembangan media game edukasi labirin matematika dilakukan uji validasi pakar media dan pakar materi. Hasil uji validasi pakar media game edukasi labirin matematika layak digunakan karena memeproleh skor 45 dengan presentase 80,3\% dengan kategori sangat baik. Sedangkan hasil uji validasi pakar materi game edukasi labirin matematika layak digunakan karena memperoleh skor 40 dengan presentase 83,3\% dengan kategori sangat baik dan layak digunakan untuk diterapkan pada pembelajaran.

Media game edukasi labirin matematika yag sebelumnya sudah dilakukan uji valiadasi pakar, selanjutnya dilakukan uji kepraktisan. Pada penelitian ini, hanya dilakukan sampai dengan uji kepraktisan dengan 
melakukan uji terbatas yang melibatkan 4 siswa. Uji coba media ini dilakukan di SD Negeri Dukuh 01 Salatiga. Setelah diberikan media game edukasi labirin matematika, siswa diminta untuk mengisi angket. Hasil agket respon siswa akan digunakan sebagai dasar untuk mengetahui kepraktisan dari media yang sudah dikembangkan.

Pada tahap terakhir yaitu evaluasi, bertujuan untuk menganalisis uji kevalidan dan kepraktisan dari media yang dikembangkan. Penelitian ini hanya dilakukan sampai pada uji kepraktisan saja dikarenakan adanya pandemi Covid-19 yang tidak menungkinkan untuk melakukan uji coba secara luas. Dari hasil uji kevalidan dan kepraktisan, terlihat jelas bahwa media game edukasi labirin matematika mendapatkan yang baik dan dapat diterapkan di sekolah dasar.

Hasil penelitian yang hampir sama dengan penelitian ini yaitu "Pengembangan Edukasi "Labirin Matematika" sebagai Media Latihan Soal Materi Bilangan" oleh Erva Vorika pada tahun 2019. Berdasarkan hasil penelitian terhadap media pembelajaran matematika berbasis edukasi, media dapat memotivasi siswa untuk belajar matematika. Hasil kevalidan menunjukkan bahwa dari ahli media adalah 73,43 dengan kategori "valid" sedangkan kevalidan "Labirin Matematika" dari ahli materi adalah 75 dengan kategori "valid. Keunggulan media pembelajaran matematika berbasis edukasi ini adalah: a. Tidak memerlukan spesifikasi tinggi untuk memainkan . b. Resolusi dan tingkat kualitas grafis bisa atur sesuai spesifikasi komputer. c. Sudah menggunakan standart FPS controller untuk memudahkan player bergerak menyusuri terrain. d. Soal sudah diacak menggunakan script random, sehingga siswa tidak bisa saling mencontek atau tukar jawaban.

Penelitian yang sama dilakukan oleh Santi Ratna, dkk pada tahun 2019 dengan judul "Pengembangan multimedia interaktif penjumlahan pada bilangan bulat untuk siswa kelas IV Sekolah Dasar". Berdasarkan hasil penelitian terhadap media pembelajaran matematika berbasis multimedia interaktif, media dapat memotivasi siswa untuk belajar matematika. Hasil akhir evaluasi oleh ahli materi termasuk dalam kategori "Sangat Baik" dengan rerata skor 3,56. Hasil akhir evaluasi oleh ahli media termasuk dalam kategori "Baik" dengan rerata skor 3,28. Hasil akhir evaluasi oleh siswa termasuk dalam kategori "Baik" dengan rerata skor 3,36. Kelebihan produk yang dikembangkan yaitu: (1) memadukan berbagai jenis media sehingga lebih menarik dan menimbulkan motivasi belajar, (2) bersifat interaktif sehingga dapat digunakan untuk belajar mandiri, (3) terdapat fitur pengulangan sehingga dapat mengakomodasi siswa yang lambat belajar, (4) memberikan pilihan menu yang beragam sehingga siswa dapat memilih menu yang diinginkan, dan (5) berbentuk software aplikasi sehingga praktis dapat digunakan di mana saja dan kapan saja.

Penelitian serupa juga dilakukan oleh Rahman Haryadi dan Novi Adriati pada tahun 2020 dengan judul "Pengembangan Berbasis Android untuk Meningkatkan Minat Belajar Materi Operasi Hitung Bilangan Bulat" Berdasarkan hasil penelitian terhadap media pembelajaran matematika berbasis android, media dapat memotivasi siswa untuk belajar matematika. Diperoleh hasil belajar siswa setelah diberikan perlakuan media s mengalami peningkatan dari 68,48 menjadi sebesar 74,11 atau terjadi peningkatan sebesar $92 \%$. Hasil penilaian para ahli menyatakan bahwa media pembelajaran s Tik Tak Boom berbasis android dalam materi operasi hitung bilangan bulat layak digunakan.

Penelitian lain dilakukan oleh Aftiani pada tahun 2018 dengan judul "Pengembangan Media Labirin Math Story Dalam Pembelajaran Materi Bangun Ruang Kelas V SD" Berdasarkan hasil penelitian, produk tersebut mampu meningkatkan hasil belajar siswa sehingga produk tersebut layak untuk digunakan. Berdasarkan penilaian siswa kelas V memperoleh nilai $76,06 \%$ terhadap ketertarikan media labirin math story. Hasil uji t memperoleh hasil yang signifikan. Hasil yang diperoleh thitung 5,77\% dan tabel $1,671 \%$. Hal ini menunjukkan bahwa terdapat perbedaan nilai rata-rata pada kelas yang menggunakan media labirin math story dan kelas yang tidak menggunakan media.

Penelitian lain dilakukan oleh Novita Ely Wardhani pada tahun 2020 dengan judul "Pengembangan Media Labyrinth Adventure Berbasis Andorid Sesuai Tahapan Pemecahan Masalah Polya di Sekolah Dasar". Berdasarkan hasil penelitian, produk tersebut mampu meningkatkan hasil belajar matematika siswa sekolah dasar. Dengan hasil pengembangan media ini pada validasi materi memperoleh persentase $94 \%$ dan pada validasi media memperoleh persentase $87,5 \%$. Pada tahap implementasi yang dilakukan pada siswa kelas IV memperoleh persentase angket rata-rata $89,7 \%$ dan persentase hasil observasi rata-rata $95 \%$. Sehingga produk Labyrinth Adventure layak digunakan.

\section{Simpulan}

Berdasarkan hasil penelitian dan pembahasan, dapat disimpulkan bawa Media game edukasi labirin matematika untuk meningkatkan kemampuan pemecahan masalah siswa kelas 6 layak untuk diterapkan dalam pembelajaran. Hal ini ditunjukkan dari hasil validasi oleh pakar media dan pakar materi. Hasil uji 
validasi pakar media memperoleh skor 45 dengan presentase 80,3\% dengan kategori sangat baik. Sedangkan hasil uji validasi pakar materi memperoleh skor 40 dengan presentase $83,3 \%$ dengan kategori sangat baik. Selain itu Media game edukasi labirin matematika untuk meningkatkan kemampuan pemecahan masalah siswa kelas 6 praktis untuk digunakan dalam pembelajaran. Hal ini ditunjukkan dari hasil respon siswa kelas 6. Dari hasil angket respon siswa diperoleh skor sebanyak 230 dengan presentase $79,9 \%$ dengan kategori baik.

\section{Referensi}

Aftiani, Agustin. (2018). Pengembangan Media Labirin Math Story Dalam Pembelajaran Materi Bangun Ruang Kelas V SDI ALMAARIF 01 Singosari. Etheses of Maulana Malik Ibrahim State Islamic University.

Agustina, Putri. 2011. Psikologi Perkembangan. Surakarta: PGSD UMS.

AH Sanaky, H. (2013). Media Pembelajaran Interaktif-Inovatif. Yogyakarta: Kaukaban Dipantara.

Alfian Mucti, Maharani Izzatin, Nurmala R. (2018). Pengembangan Media "Card 24" Pada Siswa SD Kelas V Dalam Operasi Hitung Bilangan Bulat. Jurnal Pendidikan Matematika Vol. 6, No 1

Ali Ikwan, Moch. Subchan Mauluddin, Mustagfirin Mustagfirin. (2017). Aplikasi Game Edukasi Matematika Fish Math Berbasis Android. Prosiding SNST Fakultas Teknik.

Arsyad, Azhar. 2002. Media Pembelajaran, edisi 1. Jakarta: PT. Raja Grafindo Persada.

Azhar Arsyad. 2004. Media Pembelajaran. Jakarta: PT. Raja Grafindo Persada.

Basuki, Sulistyo. 2010. Metode Penelitian. Jakarta : Penaku

Clements, D.H. \& Sarama, J. (2009). Learning and teaching early math: the learning trajectories approach. New York: Routledge.

Daryanto (2010). Media Pembelajaran. Yogyakarta: Gava Media

Depdiknas .2003. Undang-undang RI No.20 tahun 2003.tentang sistem pendidikan nasional.

Dewi, Santi Ratna. (2018). Pengembangan Multimedia Interaktif Penjumlahan Pada Bilangan Bulat untuk Siswa Kelas IV Sekolah Dasar. Jurnal Pendidikan Dasar dan Pembelajaran 9 (1): 9-22.

Dwi Wulandari, Aprillia. (2018). Pengembangan Game Maze Berbasis Media Interaktif Sesuai Tema Untuk Anak Usia 5-6 Tahun di TK Izzudin Palembang. Jurnal Pendidikan Anak Vol 7, No 1.

Erva Viorika. (2019). Pengembangan Game Edukasi "Labirin Matematika" Sebagai Media Latihan Soal Materi Bilangan". Digital Library. UIN Sunan Ampel.

F Astrini, NM Ratminingsih, I Utami - Journal of Education Research and Evaluation, 2020

Fuad ihsan. 2005. Dasar-dasar Pendidikan.Jakarta: PT Rineka Cipta.

Kemendikbud .(2016). Permendikbud Nomor 22 Tahun 2016 Tentang Standar Proses Pendidikan Dan Menengah. Jakarta: Kemendikbud

Kemendikbud. (2013). Permendikbud No. 109 tentang Penyelenggaraan Pendidikan Jarak Jauh pada Pendidikan Tinggi. Jakarta: Kementrian Pendidikan dan Kebudayaan.

Malone, T. W., \& Lepper, M.R. (1987). Making learning fun: A taxonomic model of intrinsic motivations for learning. In R.E. Snow \& M.J. Farr (Eds.), Aptitude, learning, and instruction: Vol.3. Conativeand affectiveprocessanalysis (pp.255-286). Hillsdale, NJ: Erlbaum.

Maman, Fathurrohman dan Hepsi, Nindiasari dan Ilmiyati, Rahayu (2008). Mengembangkan Board Game Labirin Matematika Bagi Siswa Kelas Rendah Guna Menghindari Mind in Chaos Terhadap Matematika. Journal Universitas Negeri Yogyakarta.

Mawardi, M. (2018). Merancang Model dan Media Pembelajaran. Scholaria: Jurnal Pendidikan Dan Kebudayaan, 8(1), 26-40.

Oemar Hamalik. 2001. Proses Belajar Mengajar. Jakarta: PT Bumi Aksara

Prensky, Marc. 2012. From Digital Natives to Digital Wisdom. New York.

Putra ,Febriyanto Pratama. 2012. "Pembuatan Game Animasi 3D Role Playing Game Untuk Pendidikan Budaya Dengan Unity3D dan Bahasa Pemrograman C\#.". Skripsi. Surakarta: Fakultas Komunikasi dan Informatika Jurusan Teknik Informatika. Universitas Muhammadiyah Surakarta.

Rahman Haryadi dan Novi Andriati. (2020). Pengembangan Game Berbasis Android Untuk Meningkatkan Minat Belajar Materi Operasi Hitung Bilangan Bulat. Jurnal Prodi Pendidikan Matematika (JPPM). Vol 2, No 1.

Safitri, Wahyu Candra Dwi. (2019). Pengembangan Media Board Game Dalam Pembelajaran Tematik Untuk Meningkatkan Kemampuan Komunikasi Dan Pemecahan Masalah. Salatiga: Repository UKSW.

Wahyudi, \& Anugraheni, I. (2017). Strategi Pemecahan Masalah Matematika. Salatiga : Satya Wacana University Press.

Wulandari Dwi A. (2013). Game Edukatif sejarah Komputer Menggunakan Role Playing Game (RPG) Maker Xp Sebagai Media Pembelajaran Di Smp Negeri 2 Kalibarang.

Yunus, Mursid, Dkk. (2015). Game Edukasi Matematika untuk Sekolah Dasar. Jurnal Informatika Mulawarman. 10(2): 59-64. 